Humaniora. Czasopismo Internetowe

$\mathrm{Nr} 4$ (28)/2019, ss. 17-38

\author{
KS. MAREK SOŁTYSIAK \\ Uniwersytet Papieski Jana Pawła II w Krakowie \\ Wydział Filozoficzny, Katedra Filozofii Poznania \\ e-mail: marek.soltysiak@upjp2.edu.pl \\ ORCID ID: 0000-0003-4437-0321
}

\title{
Próba przezwyciężenia doktryny podwójnej prawdy przez Galileusza
}

\begin{abstract}
The article is an attempt to answer the question of whether Galileo has overcome the doctrine of double truth in Copernican letters. The answer to this question is not unequivocal, just as the 'Galileo case' is unequivocal. As it is well known, the attempt to defend Copernicanism ended tragically for him. He had to revoke his view that the Earth revolves around the Sun. Also, as for the „evidence” presented by him on this matter, it proved to be either insufficient or false. However, the principle of the autonomy of science and faith, his emphasis on the authority of scientific knowledge and the authority of the Bible survived the period of condemnation of his thoughts and made itself felt in the nineteenth century, and today they determine the fides et ratio relation.
\end{abstract}

Keywords: Galileo Galilei, doctrine of the double truth, Copernicanism

alileusz, a właściwie Galileo Galilei (1564-1642), zwany także Pizańczykiem $\exists$ od miejsca swych narodzin (Piza), dla wielu współczesnych naukowców, zwłaszcza przyrodników, jest wzorem do naśladowania ${ }^{1}$. Jego dzieje, związane

${ }^{1}$ Galileusz był i jest uważany przez wielu ludzi za idealistę. Jest wzorem do naśladowania dla młodych naukowców, jako „męczennik nauki”, genialny odkrywca i pomysłowy wynalazca. Jednak jego postrzeganie przez osoby mu współczesne było całkiem odmienne. Miał grono przyjaciół, ale także liczną grupę przeciwników i to nie tylko ze względu na głoszone przez niego poglądy, ale przede wszystkim ze względu na jego charakter. Por. W. Hehl, Galileo Galilei kontrovers. Ein Wissenschaftler zwischen Renaissance-Genie und Despot, Springer Vieweg, Wiesbaden 2017. 
z „pierwszą sprawą Galileusza”, która zakończyła się najpierw upomnieniem w 1616 r., a następnie potępieniem Pizańczyka przez Inkwizycję w 1633 r. w związku z jego opowiedzeniem się po stronie Kopernika (ruchu Ziemi), są powszechnie znane $^{2}$. „Druga sprawa Galileusza” jest sporem uczonych o wartość jego nauki, o jego wkład w rozwój fizyki, astronomii i metodologii nauk, o jego stosunek do Kościoła, a przede wszystkim o relację pomiędzy nauką a prawdą Pisma św. ${ }^{3}$

Galileusz był wiernym wyznawcą Kościoła katolickiego ${ }^{4}$, niemniej jednak miał trzy obszary konfliktu z nim, były to: astrologia ${ }^{5}$, przekonania atomistyczne ${ }^{6}$ i opowiedzenie się po stronie kopernikanizmu. Spór historyków o „sprawę Galileusza” nasilił się w XIX wieku. Pizańczyk był oceniany często jednostronnie i upraszczająco. Przez niektórych był uważany wręcz za świętego Kościoła, przez innych za heretyka, a Galileusz jest przede wszystkim olśniewającą postacią renesansu, a jego związek z nauką, historią i Kościołem okazuje się o wiele bardziej złożony niż czarno-biała grafika.

${ }^{2}$ Por. Dokumentacja procesu Galileusza, tłum. M. Olszańska, K. Sławińska, A. Szostkiewicz, w: J. Życiński (red.), Sprawa Galileusza, Wydawnictwo Znak, Kraków 1991, ss. 89-115; W.W. Osterhage, Galileo Galilei. At the Threshold of the Scientific Age, Springer, Wachtberg 2018; A. Fantoli, Galileo and the Church, w: W. Applebaum (red.), Encyclopedia of the Scientific Revolution from Copernicus to Newton, Taylor \& Francis Group, New York - London 2000, ss. 392-397; E. McMullin (red.), The Church and Galileo, University of Notre Dame Press, Notre Dame, Indiana 2005. O napięciu pomiędzy stylem myślenia naukowców a stylem myślenia ludzi Kościoła pisze George V. Coyne. Por. G.V. Coyne, Galileo: for Copernicanism and for the Church, „Zagadnienia Filozoficzne w Nauce” XXXII, 2003, ss. 5-12.

${ }^{3}$ O jednej z przyczyn potępienia Galileusza pisał Jan Paweł II: „Teologowie w większości nie dostrzegli formalnego rozróżnienia między Pismem Świętym a jego interpretacją, wskutek czego niesłusznie przenosili w sferę doktryny wiary kwestię, która w rzeczywistości stanowi przedmiot badania naukowego". Jan Paweł II, Przemówienie do Papieskiej Akademii Nauk 31 października 1992 r. Sprawa Galileusza lekcjq dla współczesnych, w: idem, Dzieła zebrane, t. XIV: Homilie i przemówienia okolicznościowe, Wydawnictwo M, Kraków 2009, s. 526.

${ }^{4}$ Por. A. Fantoli, Galileusz po stronie Kopernika i po stronie Kościoła, tłum. T. Sierotowicz, Biblos, Tarnów 2001.

${ }^{5}$ Galileusz przez większą część swojego życia był aktywnym astrologiem. Astrologia stanowiła dla niego ważne źródło dochodów. Jednak większość jego tekstów o treści astrologicznej nie zachowało się do naszych czasów. Z bogatego zbioru sporządzonych przez niego rysunków astrologicznych ocalało tylko dwadzieścia pięć, wraz z postawionymi horoskopami, odpowiednimi interpretacjami i analizami. W 1604 r. doszło prawie do pierwszego procesu Galileusza przed Inkwizycją w sprawie głoszenia przez niego „fatalistycznej” astrologii. Por. W. Hehl, Galileo Galilei kontrovers..., s. 30. Por. także: D. Rutkin, Astrology, w: K. Park, L. Daston (red.), Cambridge history of science, t. 3, Cambridge University Press, Cambridge 2008, ss. 541-561; G. Oestmann, H.D. Rutkin, K. von Stuckrad (red.), Horoscopes and Public Spheres. Essays on the History of Astrology, Walter de Gruyter, Berlin - New York 2005.

${ }^{6}$ Galileusz rozumiał strukturę rzeczy jako nagromadzenie najmniejszych niepodzielnych cząstek. Jego atomistyczna koncepcja była trudna do pogodzenia z teologicznym poglądem podkreślanym przez Sobór Trydencki o prawdziwej przemianie chleba i wina w ciało i krew Chrystusa. 
Obfitość literatury na jego temat jest przytłaczająca, w 1963 r. oszacowano publikacje, które dotyczyły „sprawy Galileusza”, na około 6 tysięcy prac, w 1980 r. było ich już 8 tysięcy ${ }^{7}$. Do tego zbioru dochodzi dwudziestotomowe wydanie dzieł Galileusza i około pół miliona mniej lub bardziej trywialnych artykułów internetowych. Na początku XXI wieku liczba prac naukowych po jego rehabilitacji dokonanej przez Kościół, za przyczyną Jana Pawła II ${ }^{8}$, zdecydowanie przekroczyła 10 tysięcy woluminów.

W niniejszym artykule, w „sprawie Galileusza” interesuje mnie związek Biblii i teologii z nową nauką, a w szczególności odpowiedź na pytanie, czy Pizańczykowi udało się przezwyciężyć doktrynę dwóch prawd. Problematyka tej doktryny kładzie się cieniem na relacje nauki do teologii od 1277 r., kiedy to Stephen Tempier ${ }^{9}$, biskup Paryża, wydał dekret potępiający 219 tez. Galileusz doskonale zdawał sobie sprawę, że popierając kopernikanizm, wikła się w doktrynę podwójnej prawdy ${ }^{10}$. Pismo św. stwierdza expresis verbis, że Ziemia jest nieruchoma, a wokół niej krąży Słońce ${ }^{11}$. Heliocentryczna teoria Kopernika głosi coś całkiem przeciwnego. Jeżeli przyjąć, że obie strony mówią prawdę, to mamy do czynienia z klasyczną teorią dwóch prawd. Ruch Słońca jest prawdziwy, jeżeli rozważany jest w teologii, a fałszywy, jeżeli rozważać go będziemy w astronomii ${ }^{12}$.

\section{${ }^{7}$ W. Hehl, Galileo Galilei kontrovers..., s. 9.}

8 „Rehabilitacja” Galileusza przeprowadzona w latach 1979-1992 r. z inicjatywy Jana Pawła II rzeczywiście odbyła się, chociaż była nieformalna, częściowa i niekompletna. Por. G.V. Coyne, The Church's Most Recent Attempts to Dispel the Galileo Myth, w: E. McMullin (red.), The Church and Galileo, Notre Dame, Indiana: University of Notre Dame Press 2005, ss. 340-360. Galileusz został zrehabilitowany 2 listopada 1992 r. przez Jana Pawła II. Zapisy jego procesu zostały udostępnione nauce w 2008 r. Por. W.W. Osterhage, Galileo Galilei..., ss. 139-140.

${ }^{9}$ Por. J.F. Wippel, The Parisian Condemnations of 1270 and 1277, w: J.J. E. Gracia, T.N. Noone (red.), A Companion to Philosophy in the Middle Ages, Blackwell Publishing, Malden Oxford - Melbourne - Berlin 2002, s. 65.

${ }^{10}$ Na temat doktryny podwójnej prawdy por. J. Woleński, Powrót do teorii dwóch prawd, „Filozofia i Nauka” 1(14)/2006, ss. 45-58; B. Brożek, The Double Truth Controversy. An Analytical Essay, Copernicus Center, Kraków 2010; por. także: M. Pine, Double Truth, w: Ph.P. Wiener (red.), Dictionary of the History of Ideas, vol. II, Charles Scribner's Sons, New York 1973, ss. 31-37; D. Piché, Parisian Condemnation of 1277, w: H. Lagerlund (red.), Encyclopedia of Medieval Philosophy. Philosophy Between 500 and 1500, Springer, Dordrecht - Heidelberg London - New York 2011, ss. 910-917.

${ }^{11}$ Bóg „tak utwierdził świat, że się nie zachwieje” (Psalm 93; w. 1). „Pokolenie przychodzi i odchodzi, a Ziemia trwa po wszystkie czasy. Słońce wschodzi i zachodzi, i na miejsce swoje spieszy z powrotem, i znowu tam wschodzi” (Księga Koheleta 1; 1,4-5). Podczas walk Izraelitów z Amorytami Słońce zatrzymało się na niebie, aż Jozue odniósł zwycięstwo (Jozue 10,12-15).

12 Samo zdefiniowanie tego, czym jest podwójna prawda. sprawia pewne trudności. Woleński w związku z tym proponuje dwojakie jej rozumienie: „Wedle jednej prawda wiary i prawda wiedzy są z konieczności niezgodne, a wedle drugiej wiara i wiedza kształtują różne porządki epistemologiczne, które są ani zgodne, ani niezgodne. Przy drugim rozumieniu teoria dwóch prawd obejmuje całe spektrum stanowisk, do których należą m.in. Abelard, Ockham, Spinoza, Kant, fideizm czy modernizm (jako filozofia religii). Takie właśnie ujęcie usprawiedliwia ale- 
Argumenty biblijne i teologiczne Galileusza dotyczące zależności między nową nauką a Pismem św. i teologią, a w szczególności dotyczące problematyki podwójnej prawdy, znajdują się głównie w serii jego listów i notatek, które powstały od 1613 do 1615 r., a przede wszystkich w „listach kopernikańskich”: w Liście do o. Benedetto Castellego z 21 grudnia 1613 r. ${ }^{13}$; w dwóch Listach do Mons. Piero Diniego z 16 lutego 1615 oraz z 23 marca 1615 r.; a przede wszystkim w Liście do Wielkiej Księżnej Krystyny Lotaryńskiej z 1615 r. ${ }^{14}$ Ten ostatni list ze względu na jego walory egzegetyczne został nazwany przez Jana Pawła II „małym traktatem o hermeneutyce biblijnej”15. Listy kopernikańskie, chociaż prywatne, docierały do licznych odbiorców. Zasadniczym ich celem było upowszechnianie kopernikanizmu i wywieranie nacisku na wpływowych duchownych i uczonych. Galileusz przedstawił w nich systematyczną odpowiedź na zarzuty przeciwników kopernikanizmu. Byli oni przekonani, że astronomia kopernikańska i jej implikacje dla fizyki, kosmologii i metafizyki Arystotelesa stanowią poważne zagrożenie zarówno dla tradycyjnej interpretacji Biblii, jak i dla całego gmachu teologii katolickiej.

Teologiczna przenikliwość Galileusza była przedmiotem analiz różnych komentatorów. Między innymi Giorgio di Santillana w swej pracy pod tytułem The Crime of Galileo wyraził pochwałę dla niego jako teologa ${ }^{16}$. Jego zdaniem, gdyby w Rzymie, w czasie pierwszego kryzysu w 1616 r., pojawił się naukowiec tej miary co Tomasz z Akwinu, zamiast wiekowego Bellarmina, to z pewnością sytuacja Galileusza byłaby zupełnie inna. Przenikliwość teologiczna Galileusza w niczym nie ustępowała dokonaniom Ambrożego, Augustyna czy Bonawentury. Treść jego listów kopernikańskich odrzuconych i oskarżonych przez Święte Oficjum o herezję stała się oficjalną doktryną Kościoła od 1893 r. ${ }^{17}$

W niniejszym artykule spróbuję przybliżyć stanowisko teologii w czasach Galileusza wobec nowej nauki, a w szczególności jej odniesienie do heliocentrycznej teorii Kopernika. Przeanalizuję też argumenty biblijne i teologiczne sformułowane w obronie kopernikanizmu przez Galileusza w listach kopernikańskich, z uwzględnieniem tych argumentów, które umożliwiły mu uniknięcie zarzutu głoszenia doktryny podwójnej prawdy.

goryczne rozumienie świętych tekstów, co zalecał już Abelard, a po nim Spinoza”. J. Woleński, Powrót do teorii dwóch prawd, s. 50.

${ }^{13}$ Galileo Galilei, List do o. Benedetto Castellego z 21 grudnia 1613 roku, tłum A. Adamski, w: idem, Listy kopernikańskie, tłum. T. Sierotowicz i A. Adamski, Biblos, Tarnów 2006, s. 35.

${ }^{14}$ List ten, podobnie jak List do o. Benedetto Castellego, krążył wśród zainteresowanych jako rękopis. Pierwsze jego wydanie miało miejsce w Strasburgu w roku 1636. Por. A. Fantoli, Galileusz..., s. 217.

${ }^{15}$ Por. Jan Paweł II, Przemówienie do Papieskiej Akademii Nauk - 31 października 1992 r. Sprawa Galileusza..., ss. 523-524.

${ }^{16}$ G. de Santillana, The Crime of Galileo, Chicago, The University of Chicago Press, Chicago, Illinois 1995, s. XVIII.

${ }^{17}$ W 1893 r. Leon XIII ogłosił encyklikę Providentissimus Deus, która zawierała m.in. zasady interpretacji Pisma św., w swojej treści nawiązujące do tez głoszonych przez Galileusza w listach kopernikańskich. 


\section{Teologiczne argumenty przeciw kopernikanizmowi}

Argumenty teologiczne przeciw heliocentrycznemu systemowi Kopernika (nowej nauce) zawarł kardynał Robert Bellarmin (1542-1621) w Liście do o. Paolo Antonio Foscariniego z 12 kwietnia 1615 roku oraz Maffeo Barberini (1568-1644), późniejszy papież Urban VIII (1623-1644), w rozmowie z Galileuszem ${ }^{18}$. Teolog karmelitański o. Paolo Foscarini (1565-1616) opublikował krótką pracę w formie listu do generała zakonu karmelitańskiego, w którym bronił „bezwarunkowo prawdopodobnego" systemu Kopernika przed atakami teologów ${ }^{19}$. Powoływał się przy tym na argumenty, których użył niezależnie od niego Galileusz w Liście do o. Benedetto Castellego z 21 grudnia 1613 roku. Ich bliskie podobieństwo świadczy o tym, iż można je uznać za zdroworozsądkową odpowiedź na konflikt między nową nauką a Pismem św. w sprawach przyrodniczych. Jeżeli teologowie, według o. Foscariniego, wezmą pod uwagę zasadę akomodacji w rozumieniu Biblii, to pozorny konflikt pomiędzy teorią Kopernika a Biblią zniknie. Język Pisma św. jest językiem „zwykłych ludzi”. Celem, któremu podporządkowana jest jego treść, jest zbawienie ludzi, a nie nauka dotycząca natury wszechświata. Zdaniem o. Foscariniego połączenie tych dwóch zasad powinno odeprzeć sprzeciw Kościoła wobec kopernikanizmu, bez potrzeby dalszego argumentowania.

Na list o. Foscariniego odpowiedział kardynał Bellarmin, wybitny teolog jezuicki, jedna z czołowych postaci Inkwizycji ${ }^{20}$. Był on świadom, w jakiej sytuacji znalazł się Kościół katolicki w wyniku reformacji, która podważyła autorytet Kościoła jako jedynego, prawowitego interpretatora Pisma św. Jego zdaniem, jak również zdecydowanej większości ówczesnych teologów, kopernikańska teza o ruchu Ziemi i spoczynku Słońca rozumiana jako prawdziwy opis świata jest sprzeczna: (1) z filozofią scholastyczną, (2) z orzeczeniami Soboru Trydenckiego (1545-1563), (3) z Biblią, (4) oraz z powszechną opinią Ojców Kościoła.

Ad. 1. W Liście do o. Foscariniego Bellarmin przestrzega karmelitę oraz Galileusza przed popieraniem i rozpowszechnianiem teorii Kopernika jako prawdziwego opisu świata. Wskazuje w nim na dwa zagrożenia, jakie pociąga za sobą propagowanie heliocentryzmu. Jego rozpowszechnianie „drażni filozofów i teologów scholastycznych”, ponieważ podważa arystotelizm dominujący na ówczesnych uniwersytetach i w teologii. Ale największą szkodę jego upowszechnianie może

${ }^{18}$ A. Fantoli, Galileusz..., ss. 281-282. Barberini zwrócił uwagę Galileuszowi, iż nie można wykazać prawdziwości teorii Kopernika, można natomiast przyjąć ją jako użyteczną hipotezę badawczą.

${ }^{19}$ Por. ibidem, ss. 159-165; E. McMullin, Galileo's Theological Venture, Zygon” vol. 48, no. 1, March 2013, ss. 207-209.

${ }^{20}$ Przewodził procesowi i egzekucji Giordana Bruna w 1600 r. Był także oficjalnym przeciwnikiem Galileusza podczas kontrowersji kopernikańskiej z 1615 r. Robert Bellarmin został beatyfikowany w 1923 r., a kanonizowany w 1932 r. 
wyrządzić „Świętej Wierze, zadając kłam Pismu Świętemu”21. W związku z takim stanem rzeczy Bellarmin zaleca, aby poglądy Kopernika dotyczące ruchu Ziemi uważać za hipotezę ex suppositione. Według niego Kopernik nigdy nie głosił w sposób absolutny poglądu, że Ziemia się porusza, a Słońce jest w bezruchu²2.

Albowiem teoria, że Ziemia się porusza, zaś Słońce stoi w miejscu, i że takie hipotezy lepiej niż ekscentryki i epicykle wyjaśniają obserwowane zjawiska, wydaje się być bardzo dobra i jako taka nie pociąga ona żadnych niebezpieczeństw, a to winno wystarczyć matematykom ${ }^{23}$.

Kardynał wskazał na możliwość zaakceptowania hipotezy Kopernika tylko pod warunkiem, że będzie uważana za hipotezę matematyczną tłumaczącą określone zjawiska, a nie odzwierciedlającą faktyczny stan rzeczy. Podkreślił przy tym występującą różnicę pomiędzy dowodem wynikającym z przyjęcia hipotezy ex suppositione, że Słońce jest w centrum świata, a dowodem związanym z realnym stanem rzeczy.

Nie jest bowiem tą samą rzeczą udowodnić, że udaje się wyjaśnić pewne zjawiska, jeśli założy się, iż Słońce znajduje się w centrum świata, zaś Ziemia na niebie, oraz udowodnić, że w istocie rzeczy [in verità] Słońce znajduje się w centrum świata, zaś Ziemia na niebie. Dowód pierwszej z hipotez, jak sądzę, może istnieć, lecz jeśli chodzi o dowód drugiej, to mam poważne wątpliwości, zaś w przypadku wątpliwości nie należy porzucać Pisma Świętego wyłożonego przez świętych Ojców²4.

Inaczej mówiąc, dla przeprowadzenia obliczeń, np. w przypadku reformy kalendarza, można przyjąć hipotezę Kopernika ${ }^{25}$, że Słońce jest w centrum wszechświata, ale to nie znaczy, że została ona udowodniona. Przypomnijmy, co Andreas Osiander (1498-1552) w związku z tym napisał we wstępie do De revolutionibus Kopernika: „Nie potrzebują bowiem te hipotezy być prawdziwe, ani

${ }^{21}$ Por. R. Bellarmin, List do o. Paolo Antonio Foscariniego z 12 kwietnia 1615 roku, tłum. T. Sierotowicz, w: Galileo Galilei, Listy kopernikańskie, s. 93. Bellarmin nauczał kosmologii na Uniwersytecie w Louvain w latach 1570-1572. Wyróżniał trzy odrębne sensy duchowe Pisma św.: alegoryczny (allegoria - odniesienie do Chrystusa i Kościoła), tropologiczny albo moralny (moralis - należy żyć według Bożych kryteriów) oraz anagogiczny (anagogia - sens odnoszący się do życia wiecznego). Por. W.E. Carroll, Galileo and the Interpretation of the Bible, „Science \& Education” vol. 8, no 3, 1999, s. 161.

${ }^{22}$ Wydaje się, że Bellarmin znał poglądy Kopernika tylko z przedmowy Andreasa Osiandera, a nie z treści samego dzieła. Niektórzy uczeni uważają, że także Galileusz nie przeczytał dzieła Kopernika. Por. W. Hehl, Galileo Galilei kontrovers..., s. 242.

${ }^{23}$ R. Bellarmin, List do o. Paola Antonio Foscariniego..., s. 93.

${ }^{24}$ Ibidem, s. 94.

${ }^{25}$ Mikołaj Kopernik został wezwany przez papieża Leona X do Rzymu w celu reformy kalendarza: „zgodnie z jego nauką, nie tylko został poprawiony kalendarz, ale również ułożono tablice wszystkich ruchów planet”. Galileo Galilei, List do Wielkiej Księżnej Krystyny Lotaryńskiej z 1615 roku, tłum. A. Adamski, w: Galileo Galilei, Listy kopernikańskie, s. 59. 
nawet zbliżone do prawdy, lecz wystarczy to jedno, że dają obliczenia zgadzające się z obserwacjami”26.

Ad. 2. Sobór Trydencki pod wpływem reformacji wprowadził zaostrzenia w interpretacji Pisma św. Przestrzegał, żeby „nikt, kto polega na własnej roztropności w rzeczach dotyczących wiary i moralności, a wchodzących w skład nauki chrześcijańskiej [...] nie ośmielił się dawać objaśnień Pisma św. wbrew sensowi, który utrzymywała i utrzymuje święta Matka Kościół. Rzeczą bowiem Kościoła jest sądzić o prawdziwym sensie i tłumaczeniu Pisma św. Niech nikt także nie kwestionuje Pisma św. wbrew powszechnej zgodzie Ojców [...]”27. Sobór stwierdził, iż to Kościół decyduje o prawdziwej jego wykładni w sprawach odnoszących się do wiary i moralności (de Fide). W przypadku niejasności w zrozumieniu niektórych jego fragmentów należy odwołać się do tradycji, ponieważ interpretacja nie może być niezgodna z powszechną zgodą Ojców Kościoła dotyczącą ich rozumienia.

W związku z tak określonym autorytetem Kościoła przez Sobór powstaje pytanie: czy problemy dotyczące przyrody i astronomii, w tym ruchu Słońca i bezruchu Ziemi, są domeną wiary (de Fide)? Według wykładni powyższych orzeczeń Soboru dokonanej przez Bellarmina nowa nauka ${ }^{28}$, w tym także astronomia, przynależą do dziedziny wiary (de Fide). Wprawdzie nie jest ona kwestią wiary, jeśli chodzi o jej przedmiot (ex parte obiecti), to jednak jest nią ze względu na jej autora (ex parte dicentis $)^{29}$. Mianowicie, to Bóg jest nieomylnym autorem całego Pisma św., a zatem także tych fragmentów, które opisują zjawiska astronomiczne. Kardynał dodaje, że kto temu zaprzecza, ten podważa boskie autorstwo Pisma św. ${ }^{30}$ Według wykładni

${ }^{26}$ A. Birkenmajer, Komentarz (ks. I, rozdz. I-II), w: Mikołaj Kopernik, Dzieła wszystkie, t. 2, O obrotach, tłum. M. Brożek i St. Oświecimski, PWN, Warszawa - Kraków 1976, s. 327. Teoria Kopernika jako model kosmosu została opracowana teoretycznie przez Andreę Osiandera, niemieckiego teologa i naukowca, który napisał przedmowę do De revolutionibus orbium coelestium Kopernika. Osiander przewidując możliwe reakcje niektórych intelektualistów i naukowców, którzy w obliczu nowych tez kopernikańskich mogliby być oburzeni i zgorszeni, wzywa ich jako naukowiec, aby nie obwiniali autora o herezję, ponieważ wszyscy astronomowie wymyślają i wyobrażają sobie hipotezy i modele, aby móc obliczyć ruchy ciał niebieskich tak łatwo i precyzyjnie, jak to jest tylko możliwe. A ponieważ istnieją różne matematyczne modele kosmosu, astronom wybiera taki, który ułatwia mu obliczenia.

${ }^{27}$ Sobór Trydencki, sesja IV, dekret II, tekst polski, w: A. Hartliński (red.), Breviarum Fidei. Wybór doktrynalnych wypowiedzi Kościoła, Księgarnia św. Wojciecha, Poznań 1988, s. 117.

${ }^{28}$ Bellarmin ustanowił własną zasadę egzegetyczną, która znacznie wykroczyła poza deklarację Soboru Trydenckiego i tradycję teologiczną poprzedzającą Sobór. Por. E. McMullin, Galileo on science and Scripture, s. 282.

${ }^{29}$ R. Bellarmin, List do o. Paola Antonio Foscariniego..., s. 94.

30 Widać tu wpływ wieloletnich sporów Bellarmina z czołowymi teologami reformacji. Jeśli Duch Święty jest rzeczywiście głównym autorem Biblii, to dosłowny sens dotyczy całej Biblii, aż do ostatniego szczegółu. W tym momencie przepaść między Bellarminem a zwolennikami Kopernika wydaje się prawie nie do pokonania. Por. E. McMullin, Galileo on science and Scripture; P. Machamer (red.), The Cambridge Companion to Galilei, Cambridge University Press, Cambridge 2006, ss. 282-283. 
Bellarmina, te fragmenty biblijne, które odnoszą się do zagadnień przyrodniczych, w tym do kosmologii należy rozumieć według ich dosłownego brzmienia ${ }^{31}$.

Należy zaznaczyć, że ich interpretację dosłowną nie uznaje on w sposób autorytatywny za prawdę w sensie absolutnym: „gdyby zostało udowodnione, że Słońce znajduje się w środku świata, [...] i że Słońce nie krąży wokół Ziemi, lecz Ziemia wokół Słońca”, to wtedy należałoby odrzucić ich tradycyjne, literalne rozumienie. Ale w takiej sytuacji byłoby konieczne ponowne rozważenie słów Pisma św. „i należałoby wtedy raczej twierdzić, że się Pisma nie rozumie, niż zabieganie o uznanie tego rodzaju dowodu za błąd”32. Czy kardynał, biorąc pod uwagę rozwój współczesnej mu nauki, a w szczególności astronomii, rzeczywiście dopuszczał taką możliwość? Odpowiedź na to pytanie jest złożona, a mianowicie musiałby on przede wszystkim zmienić scholastyczne rozumienie dowodu. Jego koncepcja dowodu jest zgodna z koncepcją arystotelesowską, zgodnie z którą „udowodnić” oznacza ocenić coś w świetle prawdziwych zasad. Dlatego teoria Kopernika, chociaż „ratuje zjawiska”, to jednak nie udowadnia ich i jako taka nie jest prawdziwa. Można ją rozważać tylko jako prosty „model” kosmosu. Zanim przejdziemy do analizy listów kopernikańskich Galileusza, najpierw spróbujmy pokrótce scharakteryzować jego motywy zainteresowania się teorią Kopernika.

${ }^{31}$ Wydaje się, że zarówno Bellarmin, jak i Galileusz pomijają ważne rozróżnienia dokonane przez św. Augustyna dotyczące sensu dosłownego. Zazwyczaj kontrastujemy znaczenie tekstu w jego „dosłownym znaczeniu” (ad litteram) ze znaczeniem metaforycznym. Dla św. Augustyna „dosłowny” sens tekstu, czyli sens zamierzony przez autora, mógł być także metaforyczny, jak również mógł być po prostu „,niealegoryczny”. W przypadku narracji historycznej sens „,dosłowny” może „przekazywać fakt historyczny, mówiąc nam o tym, co faktycznie się stało”. Oczywiście komplikuje to fakt, że język, w którym opisane jest działanie Boga w tworzeniu świata, nie może być rozumiany dosłownie w nowoczesnym znaczeniu tego terminu. Szkoła aleksandryjska, której najbardziej znanymi członkami byli Orygenes (184-253), Klemens Aleksandryjski (150-215) i Cyryl Aleksandryjski (378-444), opowiadała się za alegoryczną interpretacją Starego Testamentu, widząc w niej zapowiedź Nowego Testamentu. Alegoryczne znaczenie nie było zamierzonym znaczeniem ludzkiego autora ani też tego, co pierwsi czytelnicy widzieli w tekście. Było ono zamierzone przez samego Boga dla późniejszych czytelników, aby mogli oni uchwycić głębszą spójność historii ludzkiego zbawienia. Szkoła antiocheńska z głównymi przedstawicielami: Janem Chryzostomem (zm. 407), Teodorem z Mopsuestii (350-428), Teodoretem z Cyru (393-457) preferowała bardziej dosłowną i historyczną interpretację. Św. Augustyn doskonale znał tę bogatą literaturę. Ogólnie rzecz biorąc, zajął centralne miejsce, poszukując najpierw dosłownego lub „właściwego” sensu, a następnie w wyjątkowych przypadkach alegorycznego, symbolicznego czy też proroczego. Por. E. McMullin, Galileo's Theological Venture, ss. 195-196.

32 Galileo Galilei, List do o. Paolo Antonio Foscariniego..., s. 94. 


\section{Zakwestionowanie przez Galileusza podstawowych zasad kosmologicznych Arystotelesa}

Nie ma pewności, kiedy Galileusz przekonał się o wyższości systemu kopernikańskiego nad heliocentrycznym ${ }^{33}$. Wprawdzie już w Liście do Keplera z 4 sierpnia 1597 r. zapewniał, iż zebrał liczne dowody świadczące o prawdziwości systemu kopernikańskiego, jednak nie opublikował ich ze względu na niezrozumienie wśród „głupców”34. Kiedy Kepler wyraził chęć pomocy w ich upublicznieniu, to korespondencja pomiędzy uczonymi urwała się na okres dwunastu lat, ponieważ takowych dowodów Galileusz nie posiadał35. Sytuacja zmieniła się jesienią 1609 r. w związku z udoskonaleniem przez niego teleskopu ${ }^{36}$. W wyniku obserwacji nieba dokonanych za jego pomocą odkrył on: „góry i inne ziemskie cechy” na Księżycu, plamy na Słońcu, cztery „księżyce” krążące wokół Jowisza i okresowe fazy oświetlenia Wenus. Wyniki swoich badań opublikował rok później w pracy Sidereus Nuncius (Gwiezdne orędzie) ${ }^{37}$. Wpływ tego dzieła okazał się destrukcyjny dla kosmologii Arystotelesa, która była od wieków standardowo nauczana na wszystkich uniwersytetach. Galileusz zakwestionował jej kluczowe elementy. Przede wszystkim Ziemia utraciła swoją wyjątkową pozycję wobec innych ciał niebieskich, ponieważ przestała być postrzegana jako jedyne centrum ich ruchów okrężnych. Dokonane odkrycia podważyły także doskonały, niezmienny charakter ciał niebieskich ${ }^{38}$.

Zwolennicy tradycyjnej kosmologii geocentrycznej w celu jej obrony odwoływali się do autorytetu Biblii. Pierwsze zarzuty wobec poglądów Galileusza pochodziły od Ludovico delle Colombe (ok. 1565-1616), który przytoczył liczne fragmenty biblijne, aby obalić teorię Kopernika. Do niego dołączył XVII-wieczny florentyński astronom Francesco Sizzi, negujący istnienie księżyców Jowisza.

33 Por. E. McMullin, Galileo on science and Scripture, s. 339.

34 Por. Galileo Galilei, A Giovanni Keplero. Padova, 4 agosto 1597, w: idem, Opere, t. 1, Tipografia Torines S. p. A., Torino 1964, ss. 855-856.

35 Por. J. Życiński, Proces Galileusza - konflikt prawdy i prawa, w: J. Życiński (red.), Sprawa Galileusza, s. 123.

36 Do tego czasu, jako profesor matematyki i filozofii przyrody na Uniwersytecie w Padwie, większość swojej uwagi poświęcał mechanice.

37 Por. A. Fantoli, Galileusz..., ss. 97-110.

38 Galileusz miał odwagę pójść o krok dalej i przedstawił swoje odkrycia jako potwierdzenie heliocentrycznego systemu świata Kopernika. Należy jednak dodać, że chociaż jego odkrycia podważyły zasady kosmologii arystotelesowskiej, to żadne z nich nie potwierdziło ruchu Ziemi. 


\section{Prawda nauki a prawda Pisma św. w Liście do o. Benedetto Castellego}

Galileusz miał świadomość, że jego opowiedzenie się po stronie kopernikanizmu może być powodem oskarżenia go przez zwolenników geocentryzmu o głoszenie doktryny podwójnej prawdy ${ }^{39}$. Postanowił więc udowodnić, że tezy Kopernika nie stanowią zagrożenia dla autorytetu Pisma św. i dla teologii. Pierwszą jego próbą wykazania pozornego konfliktu pomiędzy autorytetem Pisma św. a nową nauką (astronomią) był list skierowany do o. Benedetto Castellego (1580-1643) z 21 grudnia $1613 \mathrm{r}^{40}$

Należy zauważyć, że Pismo św. stanowiło punkt odniesienia dla ówczesnej nauki scholastycznej. Literalne rozumie Biblii w sprawach dotyczących ruchu Słońca i nieruchomości Ziemi znalazło potwierdzenie w filozofii naturalnej Arystotelesa i w geocentrycznej teorii Ptolemeusza. Większość teologów, w tym kardynał Bellarmin, uważało, iż geocentryzm jest zgodny z nauczaniem Ojców Kościoła i orzeczeniami Soboru Trydenckiego. Bez podważenia literalnego rozumienia Pisma św. odnoszącego się do zagadnień astronomicznych nie można było utrzymać teorii Kopernika jako rzeczywistego obrazu świata.

Galileusz rozpoczyna obronę teorii Kopernika od przyjęcia fundamentalnej zasady poznania, według której „Pismo Święte nigdy nie może kłamać ani błądzić, orzekając zawsze absolutną i niepodważalną prawdę”41 , ale równocześnie dodaje, że „chociaż Pismo Święte nie może się mylić, to jednak mogą pobłądzić - $\mathrm{i}$ to na wiele sposobów - niektórzy z tych, co Pismo Święte interpretują i wyjaśniają”42. Odróżnia zatem absolutną prawdę Pisma św. od jej interpretacji. Otóż interpretatorzy mogą się mylić w swoich interpretacjach. Szczególnie dotyczy to jego literalnego ${ }^{43}$

${ }^{39}$ Por. Galileo Galilei, List do o. Benedetto Castellego, ss. 35, 37.

${ }^{40}$ O. Castelli należał do zakonu benedyktyńskiego, studiował w Padwie pod kierunkiem Galileusza w latach 1604-1606, a następnie po nim objął katedrę matematyki. Był zwolennikiem kopernikanizmu i popierał działalność Galileusza. W liście z 14 listopada 1613 r. poinformował Galileusza o przebiegu rozmowy na dworze wielkiego księcia de Medici dotyczącej heliocentrycznej teorii Kopernika. Sprawozdanie z tej rozmowy dało Galileuszowi „okazję do ponownego przemyślenia niektórych ogólnych kwestii dotyczących powoływania się na Pismo Święte w dyskusjach przyrodniczych [in dispute di conclusiobi natural] oraz w kontekście innych rozważań, zwłaszcza zaś tych dotyczących pewnych miejsc w Księdze Jozuego, na które Wielka Księżna Matka, przy poparciu Najdostojniejszej Arcyksiężnej, powoływała się, wypowiadając na ich temat opinie przeczące tezie o ruchu Ziemi i spoczynku Słońca”. Galileo Galilei, List do o. Benedetto Castellego, ss. 33-34.

${ }^{41}$ Ibidem, s. 34.

${ }^{42}$ Ibidem. Podobną tezę głosili średniowieczni uczeni, którzy odróżniali prawdę bytu od prawdy jego poznania, czyli prawdę ontyczną od prawdy epistemologicznej.

${ }^{43}$ Pismo św. literalnie rozumiane rzeczywiście wskazuje na spoczynek Ziemi i ruch Słońca. Jednakże interpretacja literalna na przestrzeni dziejów chrześcijaństwa była uważana za jedną z wielu możliwych jego rozumień. W tradycji chrześcijańskiej obok literalnego tłumaczenia 
rozumienia, ponieważ „w Piśmie Świętym znajduje się wiele zdań, które wzięte w dosłownym znaczeniu sugerują coś, co różni się od prawdy”44, a dosłowne ich rozumienie może doprowadzić do sprzeczności, a nawet poważnych bluźnierstw i herezji. Szczególnie narażone na pomyłki są te przekazy biblijne, które odnoszą się do kosmologii, ponieważ rozumiane dosłownie, dostarczają „sofizmatów, paralogizmów i błędów"45.

W związku z tym powstaje pytanie: dlaczego w Piśmie św. znajdują się takie opisy świata, które rozumiane dosłownie mogą stwarzać problemy zarówno w wierze, jak i w nowej nauce? Powodem takiego stanu rzeczy jest dostosowanie języka Pisma św. do możliwości zrozumienia go przez ludzi, czyli zasada akomodacji. Bóg, jako doskonały pedagog, dostosowuje swój przekaz do „władz poznawczych ludów prostych i nieokrzesanych”46. Autorzy natchnieni, aby umożliwić ludziom zrozumienie przekazu o zbawieniu, przypisywali Bogu cechy dalekie od Jego natury, a nawet z nią sprzeczne ${ }^{47}$. Także te fragmenty Pisma św., które odnoszą się do przyrody, zostały podporządkowane celowi, jakim jest zbawienie. Dlatego ich forma i znaczenie słów różnią się od prawdy absolutnej ${ }^{48}$. Głoszenie prawdy o zbawieniu stało się przedmiotem nauczania Pisma św.

W związku z obecnością zasady akomodacji w Biblii powstają pytania: jak należy rozumieć te opisy, które odnoszą się do zagadnień przyrodniczych, oraz według jakich zasad należy je interpretować, aby nie głosić doktryny podwójnej prawdy? Aby odpowiedzieć na te pytania, należy najpierw określić źródła pochodzenia zarówno prawdy Pisma św., jak i prawdy przyrody. Otóż „Pismo Święte, jak i przyroda w równym stopniu pochodzą od słowa Bożego: to pierwsze podyktowane przez Ducha Świętego, ta druga zaś jako wierna wykonawczyni Bożych rozporządzeń”49. Mamy zatem tutaj do czynienia z podwójnym objawieniem się Boga: w Piśmie św. i w przyrodzie. Galileusz zaznacza, iż nie można objawienia w przyrodzie zredukować do objawienia w Piśmie św., ponieważ człowiek został wyposażony przez Boga w możność „doświadczania, mówienia i rozumowania”

Pisma św. występuje interpretacja alegoryczna, typiczna czy też mistyczna. Por. A. Adamski, Galileusz, kopernikanizm, Biblia, Bonami, Poznań 1995, ss. 46-48. Sytuacja zmieniła się na początku XVI wieku. Po wystąpieniu Lutra (1483-1546) w 1517 r. zagrożona została nienaruszalność rozumienia Pisma św. przez zastosowanie zasady sola scriptura. Zasada ta wyeliminowała przede wszystkim autorytet Kościoła w interpretacji Biblii.

${ }^{44}$ Galileo Galilei, List do o. Benedetto Castellego, s. 34.

45 Por. ibidem, s. 37.

46 Por. ibidem, s. 35. „[W] Piśmie Świętym znajduje się wiele zdań, które wzięte w dosłownym znaczeniu sugerują coś, co różni się od prawdy, jednak zdania te są sformułowane tak, jak są sformułowane, aby dostosować się do ignorancji pospólstwa” (ibidem, s. 34). Galileusz powtórzył tę tezę prawie dosłownie w Liście do Wielkiej Księżnej Krystyny... Por. Galilei Galileo, List do Wielkiej Księżnej Krystyny..., s. 63.

${ }^{47}$ Por. Galilei Galileo, List do o. Benedetto Castellego, s. 35.

${ }^{48}$ Por. ibidem.

${ }^{49}$ Ibidem, ss. 34-35. 
przyrody. W związku z tym byłoby czymś niezrozumiałym, gdyby Stwórca „zablokował [...] możliwość korzystania z tych władz” w celu jej poznania ${ }^{50}$.

Przyroda, w odróżnieniu od Pisma św., jest „nieubłagana i niezmienna w zakresie nadanych jej praw i jak gdyby nie troszczy się o nic więcej, jak tylko o swoje ukryte racje i sposoby działania, niezależnie od tego, czy są one rozumiane przez człowieka, czy też nie”51. Pomimo swej skrytości, zdaniem Galileusza, człowiek jest w stanie poznać jej prawa dzięki odpowiedniej metodzie badawczej, w której główną rolę odgrywają: doświadczenie (sensate esperienze), niezbite dowody (dimonstrazioni necessarie) ${ }^{52}$ oraz „zmysły i racje dostateczne”53. Naukowe poznanie przyrody umożliwia „dostęp do prawdy absolutnej”54, ponieważ jest ono potwierdzone przez „tysiące doświadczeń i tysiące niezbitych dowodów”55. Można zatem powiedzieć, iż przedmiotem nowej nauki jest przyroda, a metodą jej poznania jest eksperyment. Sprawy dotyczące przyrody, w tym astronomii, za sprawą Galileusza przestały być przedmiotem teologii, a stały się przedmiotem nowej nauki. Na potwierdzenie swojej tezy, że Biblia nie głosi prawd dotyczących przyrody, a w szczególności astronomii, wskazuje fakt, iż Pismo św. o nich tylko „napomyka, i to jakby na marginesie”56. Jeżeli więc w Biblii występują konkluzje dotyczące przyrody lub astronomii, to należy szukać ich prawdziwego sensu za pomocą nauk przyrodniczych: „dwie prawdy nigdy nie mogą przeczyć sobie wzajemnie, zadaniem mądrych egzegetów jest podejmowanie trudu szukania prawdziwego znaczenia zdań Pisma Świętego, zgodnie z konkluzjami o charakterze przyrodniczym, co do których możemy być zupełnie przekonani w oparciu o naoczne doświadczenie lub niezbite dowody"57.

Wyłączenie spraw dotyczących przyrody spod domeny prawd, o których w sposób literalny Pismo św. orzeka, pozwoliło Galileuszowi określić autonomię nauk przyrodniczych względem teologii. Po pierwsze, nauka i teologia mają odmienny przedmiot swoich zainteresowań i odmienną metodę badań. Nauka interesuje się przyrodą, natomiast Biblia ludzkim zbawieniem: „autorytet Pisma Świętego ma na celu tłumaczenie ludziom głównych artykułów wiary oraz przykazań, które - będąc konieczne do zbawienia i przekraczając możliwości ludzkiego pojmowania - nie mogą być ani przez inne nauki, ani w żaden inny sposób uwiarygodnione, jak tylko

50 Por. ibidem, s. 36.

51 Ibidem, s. 35.

52 Por. ibidem.

53 Por. ibidem, s. 36.

54 Por. ibidem, s. 37.

55 W Liście do Wielkiej Księżnej dodaje, iż to, co zostaje uznane za prawdę w naukach przyrodniczych, poparte jest „wieloma rozumnymi doświadczeniami i niezbitymi dowodami”. Por. Galilei Galileo, List do Wielkiej Księżnej..., s. 85.

56 „Jeśliby bowiem pierwsi autorzy Świętych Tekstów pragnęli wyjaśnić ludziom układ i ruchy ciał niebieskich, to nie mówiliby o nich tak rzadko”. Galilei Galileo, List do o. Benedetto Castellego, s. 36.

57 Ibidem, s. 35. 
ustami samego Ducha Świętego"58. Poznanie naukowe posługuje się eksperymentem, teologiczne odwołuje się do autorytetu Pisma św.

Po drugie, nauki nie powinny powoływać się na argumenty biblijne w dyskusjach dotyczących przyrody i astronomii. Galileusz, wbrew dotychczasowemu zwyczajowi, w którym argumenty biblijne odgrywały decydującą rolę w nauce, twierdzi dobitnie, iż „Pismo Święte winno być brane pod uwagę na ostatnim miejscu”59. Również przestrzega przed powoływaniem się na autorytet Pisma św. w celu wyjaśnienia kwestii przyrodniczych, które nie zostały jeszcze naukowo udowodnione ${ }^{60}$. Wskazuje na fakt, że poznanie naukowe jest niekończącym się procesem ${ }^{61}$, dlatego problemy naukowe, które nie zostały jeszcze uzasadnione, mogą zostać udowodnione przez naukę w przyszłości, a wtedy argumenty biblijne użyte do ich wyjaśnienia zostałyby ośmieszone. Po trzecie: teolodzy, będąc ekspertami w dziedzinie wiary, nie są nimi w dziedzinie nauki i nie mogą rościć sobie prawa do tłumaczenia kwestii przyrodniczych: „brak im wiedzy koniecznej nie tylko do oceny, ale nawet do zrozumienia dowodów, na których nauki ścisłe opierają niektóre swe konkluzje"62.

Można zatem powiedzieć, że Galileusz w Liście do o. Benedetto Castellego unika zarzutu głoszenia doktryny „podwójnej prawdy” przez wykazanie autonomii nauk przyrodniczych wobec teologii, tzn. za cenę separacji nauk przyrodniczych od teologii ${ }^{63}$.

W analizowanym przez nas Liście do o. Benedetto Castellego pojawiają się pewne trudności. (1) Dlaczego fragmenty Pisma św., które odnoszą się do zagadnień kosmologicznych, nie powinniśmy interpretować literalnie? Samo powoływanie się na heliocentryczną teorię Kopernika, która jest niezgodna z biblijnym opisem, jest niewystarczające, ponieważ jej prawdziwość nie została przez niego udowodniona. (2) Jakie jest kryterium odróżnienia interpretacji prawdziwej od fałszywej? Galileusz nie udziela odpowiedzi na te ważne pytania w powyższym liście. Odpowie na nie w Liście do Wielkiej Księżnej Krystyny z Lotaryngii.

58 Ibidem, s. 36.

${ }^{59}$ Ibidem, s. 34. W Liście do Wielkiej Księżnej stwierdza, iż wyjaśnienie problemów przyrodniczych należy rozpocząć nie od Pisma św., lecz od „rozumnych doświadczeń i niezbitych dowodów”. Galileo Galilei, List do Wielkiej Księżnej..., s. 63.

60, ,[C]o do których zmysły i racje dostateczne oraz dowody mogą kiedyś przeciwne dać świadectwo". Galileo Galilei, List do o. Benedetto Castellego, s. 36.

${ }^{61}$ „Któż chciałby twierdzić, że wszystko, co jest na świecie poznawalne, zostało już poznane" Ibidem.

${ }^{62}$ Ibidem.

63 Jego przeciwnicy we Florencji dopilnowali, aby kopia Listu do o. Benedetto Castellego trafiła do Rzymu, gdzie ostatecznie dotarła do Zgromadzenia Świętego Oficjum, arbitra Kościoła w sprawach wiary i moralności. Ale kiedy list został przekazany konsultantowi teologicznemu Kongregacji w celu osądu co do jego ortodoksji, nie wzbudził większego sprzeciwu. Debata w Rzymie nad teologiczną akceptowalnością nowych idei kosmologicznych stawała się jednak coraz bardziej intensywna w 1614 r. i na początku 1615 r. Por. E. McMullin, Galileo on science and Scripture, s. 278. 


\section{Teologiczne argumenty w obronie kopernikanizmu w Lišcie do Wielkiej Księżnej Krystyny z Lotaryngii}

Galileusz w Liście do Mons. Pierro Diniego odnosi się krytycznie do własnych argumentów użytych w Liście do o. Benedetto Castellego w obronie kopernikanizmu. List ten według jego oceny został napisany „currente calmo [bez namysłu i poprawek]”64. Dlatego postanowił wydać esej, który przekonałby rzymskich teologów do kosmologii heliocentrycznej. Dokument ten formalnie nazwany Listem do Wielkiej Księżnej Krystyny z Lotaryngii (1565-1637) matki jego patrona i byłego ucznia Ferdynanda II Medyceusza (1610-1670), wdowy po księciu Toskanii Ferdynandzie I Medyceuszu (1549-1609), de facto skierowany był do teologów i uczonych, a w szczególności do członków Inkwizycji w Rzymie ${ }^{65}$.

List do Wielkiej Księżnej został napisany przez niego z pewnością po zapoznaniu się z treścią listu Bellarmina do o. Foscariniego z 12 kwietnia 1615 r., ponieważ znajdują się w nim odpowiedzi na zarzuty kardynała dotyczące kosmologii Kopernika. Galileusz pisze w nim, iż „Według niektórych teologów zdania dotyczące spraw przyrodniczych, o których Pismo Święte wyraża się zawsze tak samo i które wszyscy Ojcowie zgodnie przyjmują w tym samym sensie, muszą być rozumiane dosłownie, bez glos i interpretacji i jako takie winny one być przyjęte oraz uważane za jak najbardziej prawdziwe. A ponieważ do tego rodzaju zdań należą twierdzenia o ruchu [Słońca] i nieruchomości Ziemi, dlatego są one w konsekwencji de Fide, natomiast opinia przeciwna winna być uznana za błędną" ${ }^{\text {"W6 }}$ W powyższym fragmencie listu Galileusz wskazał dwa kryteria przyjmowane przez Bellarmina (chociaż nie wymienia go z imienia i nazwiska) i innych teologów przemawiające za literalnym rozumieniem opisów biblijnych odnoszących się do spraw przyrodniczych, w tym do ruchu Słońca i nieruchomości Ziemi: (1) powszechna zgoda Ojców Kościoła i (2) interpretacja Bellarmina orzeczeń Soboru Trydenckiego dotycząca spraw kosmologicznych poruszanych w Piśmie św. Według niej sprawy te są przedmiotem wiary (de Fide) ze względu na autorytet Boga, który jest autorem całego Pisma św.

Ad. 1. Jeżeli chodzi o powszechną zgodę Ojców Kościoła dotyczącą spraw kosmologicznych, to Galileusz jest odmiennego zdania niż Bellarmin. Twierdzi on mianowicie, iż takiej zgody nie ma wśród Ojców ${ }^{67}$, ponieważ według starożytnej tradycji Kościoła, wywodzącej się od św. Augustyna (354-430), unikali oni

${ }^{64}$ Por. Galileo Galilei, List do Mons. Pierro Diniego z 16 lutego 1615 roku, tłum. T. Sierotowicz, w: Galileo Galilei, Listy kopernikańskie, s. 42.

${ }^{65}$ Galileusz najwyraźniej postanowił nie rozpowszechniać listu zbyt szeroko, prawdopodobnie pod wpływem rad swoich rzymskich przyjaciół, którzy uznali, że traktat o kontrowersyjnym teologicznie temacie dotyczącym interpretacji Biblii, napisany przez matematyka, może jeszcze bardziej zaszkodzić sprawie Kopernika.

${ }^{66}$ Galileo Galilei, List do Wielkiej Księżnej..., ss. 74-75.

${ }^{67}$ Por. ibidem, s. 81. 
w ogóle zajmowania stanowiska w tych sprawach. „Kiedyś mogłoby się bowiem okazać, na podstawie doświadczeń lub niezbitych dowodów, że jest inaczej niż mówi literalne znaczenie słów”68, a przez to sama Biblia zostałaby ośmieszona przez niewierzących.

Galileusz, nie mając wykształcenia teologicznego, potrzebował pomocy, aby uzupełnić swoje argumenty dotyczące obrony kopernikanizmu... autorytetem Ojców Kościoła. Prawdopodobnie zaczął zabiegać o pomoc swoich teologicznych przyjaciół w tym względzie już w 1614 r. W styczniu 1615 r. o. Castelli napisał do niego z Rzymu, że pewien barnabicki kapłan obiecał przekazać mu kilka pomocnych odniesień do pism św. Augustyna i innych Ojców Kościoła. Galileusz z pewnością wcześniej zdecydował, że to właśnie św. Augustyn będzie głównym świadkiem jego obrony. Byłby zachwycony odkryciem, że każda zasada, którą sam wypowiedział w swoim wcześniejszym Liście do o. Benedetto Castellego, znalazła precedens w De Genesi ad litteram Augustyna. W Liście do Wielkiej Księżnej cytuje co najmniej 14 fragmentów tej pracy, przeplatając je ostrym komentarzem. Ponadto odwołuje się do szeregu innych autorytetów teologicznych z wcześniejszego okresu, do: Tertuliana (155-220), św. Hieronima (327-420), Dionizego, Piotra Lombarda (1100-1160), św. Tomasza z Akwinu (1225-1274) oraz do teologów bliższych swoich czasów: Diego de Zùńiga (1536-1597), Pawła z Burgos (1351-1435), Alonso Tostado (około 1400-1455) czy Benedykta Pereiry (1535-1610).

Galileusz dzieli ze św. Augustynem przekonanie, że prawdziwy konflikt między dwoma źródłami prawdy jest niemożliwy, to znaczy, że jest niemożliwy konflikt pomiędzy Biblią a nauką. Ponownie pojawiają się w omawianym przez nas liście zasady interpretacji Biblii z Listu do o. Benedetto Castellego, niektóre zacytowane dosłownie, ale tym razem poparte łacińskimi cytatami z Ojców Kościoła dla nadania im większego znaczenia ${ }^{69}$.

Ad. 2. Dla naszych rozważań szczególnie interesująca jest odpowiedź Galileusza na pytanie: czy zagadnienia przyrodnicze, w tym także astronomiczne, są dziedziną wiary (de Fide)? Odpowiedź na to pytanie jest o tyle istotna, że rozstrzygnięcie negatywne uchroni go przed zarzutem głoszenia doktryny podwójnej prawdy, a pozytywne stanie się głównym argumentem w oskarżeniu go o głoszenie herezji. Bellarmin, interpretując orzeczenia Soboru Trydenckiego dotyczące spraw nauki, w tym astronomii poruszanych w Piśmie św., twierdził, iż są one przedmiotem wiary ze względu na jej autora, którym jest Bóg. Galileusz nie zgadza się z taką interpretacją, ponieważ w orzeczeniach Soboru Trydenckiego nie dostrzega bezpośredniego odniesienia do nauk przyrodniczych, w tym do astronomii. Według

${ }^{68}$ Ibidem.

${ }^{69}$ Ernan McMullin analizuje je szczegółowo i wykazuje podobieństwo z zasadami użytymi przez św. Augustyna w jego głównej pracy poświęconej temu zagadnieniu, w De Genesi ad litteram. Por. E. McMullin, Galileo's Theological Venture, ss. 192-220; idem, Galileo on Science and Scripture, ss. 271-347. 
niego kwestie kosmologiczne nie były bezpośrednio przedmiotem zainteresowań i orzeczeń Soboru. Sesja IV Soboru, dotycząca spraw wiary i moralności, nie mówi nic na temat przyrody i astronomii ${ }^{70}$.

Zakwestionowanie przez Galileusza powszechnej zgody Ojców Kościoła dotyczącej literalnego rozumienia Pisma św. w sprawach kosmologicznych, jak również wykazanie, iż nie stały się one przedmiotem obrad Soboru Trydenckiego, a więc, że nie są przedmiotem wiary (de Fide), podważyło roszczenie teologów do narzucenia autorytetu Biblii naukom przyrodniczym.

Skutkiem ograniczenia autorytetu Biblii wobec nauk przyrodniczych było określenie na nowo prymatu teologii wobec innych nauk. Według Galileusza

[...] teologia, zajmuje się najwznioślejszą kontemplacją spraw Bożych i w swej godności zasiadając na królewskim tronie, ze względu na najwyższy autorytet nie sięga po pośledniejsze spekulacje podrzędnych nauk. Raczej [...] nie interesuje się nimi, jako nie odnoszącymi się do szczęścia wiecznego. Stąd zajmujący się teologią i jej profesorowie nie powinni przypisywać sobie autorytetu w celu decydowania o naukach przez nich ani nie praktykowanych, ani nie studiowanych ${ }^{71}$.

Przedmiotem teologii są „sprawy Boże”, czyli sprawy odnoszące się do wiary i moralności (de Fide). Natomiast przedmiotem nauki jest przyroda, w tym także astronomia. Teolodzy nie powinni wykraczać poza swoje kompetencje i rozstrzygać spraw związanych z naukami przyrodniczymi. Ich roszczenia do posiadania autorytetu we wszystkich dziedzinach wiedzy Galileusz porównuje ironicznie do władcy absolutnego ${ }^{72}$, który nie będąc ani lekarzem, ani architektem, chciałby zarówno leczyć, jak i budować według własnego upodobania, stwarzając przy tym zagrożenie tak dla chorych, jak i dla budynków. Na poparcie swojej tezy o epistemologicznym konkordyzmie Galileusz powołuje się na autorytet św. Augustyna. Autor Wyznań w Komentarzu do Księgi Rodzaju stwierdza, iż „intencją Ducha Świętego jest nauczać nas, jak idzie się do nieba, a nie jak porusza się niebo (Kardynał Baronius)"’33.

A zatem w poznaniu mamy do czynienia z dwoma równorzędnymi autorytetami: z Pisma św. i nauki:

[...] autorytet wniosków dotyczących przyrody, prawdziwie udowodnionych, nie powinien być uważany za mniejszy od autorytetu Pisma Świętego, to należy tylko wykazać, że nie są one [wnioski] sprzeczne z Pismem Świętym ${ }^{74}$.

${ }^{70}$ Por. Galileo Galilei, List do Wielkiej Księżnej..., s. 80.

${ }^{71}$ Ibidem, s. 71.

${ }^{72}$ Por. ibidem.

${ }^{73}$ Ibidem, s. 66.

${ }^{74}$ Ibidem, ss. 72-73. Podkreślana przez Galileusza autonomia badań naukowych wobec Pisma św. stanie się w nowożytności podstawową zasadą badawczą. 
Autorytet nauk przyrodniczych jest zagwarantowany przez możliwość poznania prawdy absolutnej. Poznającemu podczas procesu poznawania narzuca się prawda. Dlatego nie można od naukowców wymagać, „aby nie tylko nie dostrzegali tego, co widzą, co wiedzą, i nie pojęli tego, co pojmują, ale aby szukając, znaleźli przeciwieństwo tego, na co się natknęli. To tak, jakby wyobraźnia i wola mogły i chciały sądzić odwrotnie, niż pojmuje rozum"75. Doświadczenie prawdy jest dla nich zniewalające. Profesorowie nauk (scienze demonstrative) jeżeli coś poznali, to nie mogą zmieniać swojego zdania, ponieważ poznane przez nich prawdy naukowe „są potwierdzone lub można je potwierdzić na podstawie doświadczeń, długich obserwacji i niezbitych dowodów"76.

W związku z autonomią nowej nauki wobec teologii powstaje pytanie: jak powinien zachować się naukowiec, gdy poznane przez niego prawdy dotyczące przyrody są sprzeczne z Pismem św.? Galileusz stoi na stanowisku, że ścisłe przestrzeganie swoich kompetencji przez naukę i przez teologię powinno wyeliminować pojawienie się sprzeczności między nimi ${ }^{77}$. Czyli podobnie jak w Liście do o. Benedetto Castellego twierdzi, że jeżeli naukowiec doszedł do jednoznacznych wniosków dotyczących zjawisk naturalnych, to egzegeta powinien odkryć na nowo w ich świetle prawdziwy sens tych fragmentów Pisma św., które do nich się odnoszą. W związku z tą odpowiedzią pojawia się następne pytanie: jak powinien postąpić naukowiec, gdy dla wyjaśnienia określonego zjawiska przyrodniczego nie dysponuje „oczywistymi i niezbitymi dowodami”, popartymi „wieloma doświadczeniami”?

Ernan McMullin ${ }^{78}$ uważa, że nawet w takim przypadku Galileusz nie zgadza się na to, aby Biblia mogła służyć jako źródło prawd o świecie fizycznym. A zatem, jeżeli określone zjawisko naturalne nie zostało jeszcze naukowo wyjaśnione, to należy poczekać na „oczywiste i dostateczne argumenty” naukowe, a nie posługiwać się argumentami z Pisma św.

Za przyjęciem takiej interpretacji świadczą słowa Galileusza z omawianego przez nas Listu do Wielkiej Księżnej, kiedy stwierdza dobitnie, iż nawet Ojciec Święty nie powinien mocą autorytetu swego urzędu potępiać hipotezy kopernikańskiej, zanim nie zostanie ona udowodniona przez naukę jako „niemożliwa i fałszywa"79. Jednak dwa inne teksty z tego samego listu zdają się przeczyć powyższej interpretacji. Po pierwsze, Galileusz, powołując się na autorytet autora Wyznań, dokonuje ważnego rozróżnienia w sytuacji, kiedy poznanie naukowe nie jest wystarczająco potwierdzone. „Święty Augustyn uważa, że jeżeli to, co mówią o niebie astronomowie, jest sprzeczne z Pismem Świętym, a jednocześnie oparte jedynie

75 Ibidem, ss. 71-72.

76 Ibidem, s. 75.

77 Por. Galileo Galilei, Fragmenty kopernikańskie, tłum. T. Sierotowicz, Wydawnictwa Uniwersytetu Warszawskiego, Warszawa 2005, s. 37.

78 Por. E. McMullin, Galileo on science and Scripture, s. 343.

79 Por. Galileo Galilei, List do Wielkiej Księżnej..., ss. 85-86. 
na domysłach słabej istoty ludzkiej, wówczas nie należy się tym zajmować, lecz

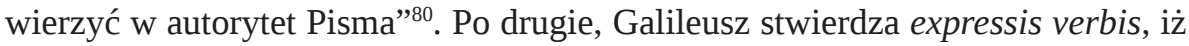
w sprawach dotyczących przyrody, czyli w dziedzinie niedotyczącej bezpośrednio wiary (de Fide), ale niepopartych stosownymi dowodami naukowymi, ,autorytet tych samych Pism Świętych winien być przedkładany ponad autorytet wszystkich pism ludzkich, nie napisanych w oparciu o metodę naukową [non con metodo dimostrativo], lecz przedstawiających jedynie racje prawdopodobne, czy będące po prostu powieściami. [...] Boża mądrość przekracza bowiem każdy ludzki osąd i wniosek"81. Powyższe wypowiedzi Galileusza wprowadzają pewien rozdźwięk w spójności jego poglądów dotyczących metodologicznego rozdziału teologii od nauk przyrodniczych.

\section{Epilog obrony kopernikanizmu}

Teoria heliocentryczna, uważana zarówno przez Galileusza, jak i przez innych zwolenników kopernikanizmu za prawdziwą, została określona w dekrecie Świętego Oficjum z roku 1616 jako bezsensowna i absurdalna z punktu widzenia filozofii ${ }^{82}$. Większość z podpisanych pod dekretem przedstawicieli Inkwizycji była przekonana, że osądzili ją zgodnie z zasadami ówczesnej nauki ${ }^{83}$. Nie uznano jej wtedy za heretycką na wyraźną prośbę kardynałów Maffeo Barberiniego oraz Antonio Caetaniego (1566-1624). Barberini był przekonany, iż „żadna teoria astronomiczna nie może rościć sobie pretensji do tego, aby być czymś więcej niż tylko hipotezą, ze względu na ograniczenia umysłu ludzkiego, który nie jest w stanie wniknąć w tajemnice zamysłu Stwórcy”84. Ten sam dekret stwierdzał, że doktryna Koper-

80 Ibidem, s. 75.

81 Ibidem, s. 64.

8224 lutego 1616 r. dekret Świętego Oficjum ocenzurował dwa zdania przypisywane Kopernikowi. Pierwsze zdanie: „Słońce stanowi centrum świata i jest całkowicie nieruchome pod względem ruchów lokalnych. [...]. Teza ta została jednogłośnie uznana za bezsensowną i absurdalną z punktu widzenia filozoficznego i formalnie heretycką, jako stojącą w wyraźnej sprzeczności z nauką Pisma Świętego”. Drugie zdanie: „Ziemia nie stanowi centrum świata, ani nie jest nieruchoma, lecz obraca się zarówno wokół samej, jak i ruchem dobowym. [...] Jednogłośnie stwierdzono, że teza ta podlega tej samej cenzurze filozoficznej, z punktu zaś widzenia teologii, jest co najmniej błędem w wierze” (Dokumentacja procesu, w: J. Życiński (red.), Sprawa Galileusza, s. 95). Por. B. Vinaty, Galileusz i Kopernik, w: J. Życiński (red.), Sprawa Galileusza, s. 64.

${ }^{83} \mathrm{Z}$ punktu widzenia samych teologów, dekret z $1616 \mathrm{r}$. nie powinien być rozumiany w ten sposób, że „teologia jest przeciwko nauce”. Galileusz został wezwany przez kardynała Bellarmina i upomniany 26 lutego 1616 r., ,aby wyrzekł się całkowicie wspomnianego poglądu, jakoby Słońce znajdowało się w pośrodku świata i było nieruchome, a Ziemia była w ruchu, i nigdy więcej go nie powtarzał, ani nauczał, ani nie podtrzymywał w żaden sposób w mowie ani w piśmie”. Dokumentacja procesu, w: J. Życiński (red.), Sprawa Galileusza, s. 96.

${ }^{84}$ A. Fantoli, Galileusz..., ss. 252-253. Barberini, wybrany na papieża w 1623 r., przybrał imię Urban VIII. „,[P]o 1616 roku nie zerwał stosunków z Galileuszem. 20 sierpnia 1620 r. prze- 
nika mówiąca o rzeczywistym ruchu Ziemi jest „sprzeczna z Pismem Świętym”. De revolutionibus zostało zakazane przez Zgromadzenie Indeksu, aż do czasu korekty „krytycznych” fragmentów mówiących o rzeczywistym ruchu Ziemi. Po dwunastu, przeważnie drobnych naniesionych poprawkach, które jednak zdegradowały książkę do hipotezy matematycznej, praca była „wolna” i można ją było ponownie wydawać i czytać od 1620 r. Sama jednak doktryna heliocentryczna jako prawda fizyczna, że „Ziemia krąży wokół Słońca”, była zakazana przez Kościół aż do $1822 \mathrm{r}^{85}$

Skutkiem dekretu z 1616 r. było odrzucenie większości egzegetycznych argumentów z Listu do o. Benedetto Castellego. Natomiast List do Wielkiej Księżnej nie jest nigdzie wymieniony w dokumentach Inkwizycji z lat 1615-1616. Pierwsze odniesienie do niego w źródłach rzymskich pojawia się dopiero w raporcie Inchofera z $1633 \mathrm{r} .{ }^{86} \mathrm{Z}$ pewnością Bellarmin nie znał jego treści przed dyskusjami Świętego Oficjum przynajmniej w 1616 r., ponieważ gdyby było inaczej, to na pewno zostałby dołączony do dokumentów Świętego Oficjum. Kardynał został zobligowany, aby uświadomić Galileusza, że decyzja Świętego Oficjum wyklucza dalszą obronę pozycji kopernikańskiej z jego strony ${ }^{87}$.

\section{Zakończenie}

Galileusz, w związku z opowiedzeniem się po stronie kopernikanizmu, stanął przed dylematem, jak wykazać prawdziwość teorii heliocentrycznej, nie narażając się na zarzut głoszenia doktryny podwójnej prawdy. Aby uniknąć tego zarzutu, musiał udowodnić, że nie jest ona sprzeczna ze świadectwami biblijnymi mówiącymi o ruchu Słońca i bezruchu Ziemi. W związku z tym sięgnął po rewolucyjne środki. Po pierwsze, wprowadził konkordyzm w poznaniu, czyli harmonię pomiędzy Pismem św. a nowożytną nauką, za cenę ograniczenia roszczeń teologów. Było to o tyle trudne, że Biblia jeszcze w XVI i XVII wieku stanowiła główne źródło prawdy nie tylko w teologii, ale praktycznie w każdej dziedzinie. Po drugie, aby wytłumaczyć nieliteralne rozumienie tych fragmentów Pisma św., które mówią o ruchu Słońca i stabilności Ziemi, sięgnął po zasadę akomodacji. A po trzecie, nadał nowe, nowożytne znaczenie pojęciu autorytetu w poznaniu.

(1) Jego rozwiązanie konfliktu pomiędzy Pismem św. a nową nauką zawarte w listach kopernikańskich z lat 1613-1615 polegało na odmowie podporządkowania wiedzy dotyczącej świata fizycznego, osiągniętej za pomocą badań empirycznych i syntezy matematycznej, autorytetowi Pisma św. Odrzucał w nich możliwość

słał mu nawet łacińską odę Adulatio perniciosa, w której wyrażał swój podziw wobec odkryć dotyczących Jowisza, Saturna i plam słonecznych”. Ibidem, s. 253.

${ }^{85}$ W. Hehl, Galileo Galilei kontrovers..., s. 242.

${ }^{86}$ Por. E. McMullin, Galileo's Theological Venture, s. 210.

${ }^{87}$ Por. E. McMullin, Galileo on science and Scripture, s. 324. 
powoływania się teologów na autorytet Biblii w sprawach dotyczących przyrody. W związku z tym zredefiniował pojęcie teologii jako „królowej nauk”, ograniczając jej kompetencję do wiary i moralności. Nauce przyznał autonomię wobec teologii, określając jej swoisty przedmiot (przyroda) i metodę badań (eksperyment).

(2) Pewne wątpliwości budzi teza Galileusza, iż nauka poznaje prawdy absolutne. Według niego naukowiec ma możliwość poznania „nieubłaganych oraz niezmiennych” praw oraz „ukrytych racji” rządzących naturą. Jest on jednym z tych filozofów, którzy zapoczątkowali oświeceniową wiarę w rozum ${ }^{88}$, pominęli występującą złudę zmysłów w poznaniu, jak również inne argumenty sceptyczne, które z taką siłą dały znać o sobie w filozofii Descartes’a. Jest to wynik tego, jak uważa Crombie, że

Galileusz pisał językiem bezkompromisowego naukowego realizmu. Był zwolennikiem świata niezmiennych praw, istniejących niezależnie od poznania ludzkiego, prawdziwego świata, którego odkrycie jest zadaniem nauki, niewątpliwie w drodze subtelnego rozumowania teoretycznego, ale niemniej jednak pewnego ${ }^{89}$.

W związku z tym należy zgodzić się z oceną McMullina, iż Galileuszowi jako naukowcowi nie udało się uchwycić tego, co było wymagane w ramach dowodu w kontekście kosmologii ani docenić epistemicznej wartości prawdopodobnego rozumowania. Dość nonszalancko traktował kategorię prawdopodobieństwa w nauce, jak również zalety dobrze uzasadnionej hipotezy ${ }^{90}$.

(3) Wydaje się, że zarówno Święte Oficjum, jak i Galileusz byli w błędzie. Inkwizycja nie zdawała sobie sprawy z tego, że sprzeczność między kosmologią heliocentryczną a Pismem św. jest pozorna. Natomiast Galileusz nie był w stanie

${ }^{88}$ Galileusz odrzucił propozycję Bellarmina, aby jego wyniki badań zostały sklasyfikowane jako prosta hipoteza, dopóki rzeczywiście nie uda się ich udowodnić. Dla niego każda myśl emanująca w jego mózgu już przedstawiała jakąś prawdę, bez względu na to, jak dziwnie może to wydawać się innym. Sugestia kardynała jest obecnie powszechną praktyką, każde twierdzenie naukowe musi być początkowo traktowane jako hipoteza. Zasada ta zostało po raz pierwszy sformułowana przez Karla R. Poppera w 1934 r. w jego Logice odkrycia naukowego. Por. W.W. Osterhage, Galileo Galilei, ss. 139-140.

${ }^{89}$ A.C.C. Crombie, Nauka średniowieczna i poczq̨tki nauki nowożytnej, t. 2, tłum. S. Łypacewicz, Instytut Wydawniczy Pax, Warszawa 1960, s. 252. Galileusz „Był przekonany również, że »twierdzenia przyrodnicze« mogą być »apodyktycznie udowodnione«, a eksperymentalna weryfikacja teorii może ustalić ją z »niezawodną pewnością«. Opisując rozpoczęcie badań za pomocą »hipotetycznego założenia«, mówi w Rozprawach..., że założenie to można przyjąć warunkowo »jako postulat, którego absolutna prawda zostanie ustalona, kiedy stwierdzimy, że wnioski z niego odpowiadają eksperymentowi i zgadzają się z jego wynikiem«. Języka tego używał nie tylko przy ustalaniu kinematycznego prawa ciał swobodnie spadających jako faktu, ale również mówiąc o teorii kopernikańskiej. Toteż gdy powtarza argument, że ta ostatnia jest bardziej ekonomiczna niż teoria Ptolemeusza, nie mówi tego w jakimś znaczeniu konwencjonalnym. Sama przyroda »nie czyni za pomocą wielu rzeczy tego, co można uczynić za pomocą niewielu«, mówi w „Drugim dniu” Dialogu...”. Ibidem, ss. 254-255.

${ }_{90}$ Por. E. McMullin, Galileo on science and Scripture, s. 318. 
udowodnić naukowo, że model świata kopernikańskiego jest w rzeczywistości prawdziwy.

(4) Zasadniczo Galileusz miał rację w swoich argumentach zawartych w Liście do Wielkiej Księżnej j1 Jego celem było wykazanie, że Kościół nie powinien zakazywać kopernikańskiego spojrzenia na świat, ponieważ taki zakaz nie jest ani racjonalny, ani teologicznie uzasadniony.

(5) Czy można sobie wyobrazić sytuację, kiedy pod wpływem rozwoju nauki, tak jak proponował to Galileusz, teolodzy katoliccy zostaliby zmuszeni do zrewidowania swoich poglądów? Jan Paweł II dopuszcza taką możliwość, stwierdzając 31 października 1992 r. przy okazji rehabilitacji Galileusza:

[...] teolodzy mają obowiązek stałego uzupełniania swej wiedzy o nowych zdobyczach nauki, tak by w razie potrzeby byli zdolni zdecydować, czy powinni je uwzględnić w swojej refleksji i zmodyfikować swoje nauczanie ${ }^{92}$.

\section{Literatura}

Adamski A., Galileusz, kopernikanizm, Biblia, Bonami, Poznań 1995.

Birkenmajer A., Komentarz (ks. I, rozd. I-II), w: Mikołaj Kopernik, Dzieła wszystkie, t. 2: O obrotach, tłum. M. Brożek i St. Oświecimski, PWN, Warszawa - Kraków 1976.

Brożek B., The Double Truth Controversy. An Analytical Essay, Copernicus Center, Kraków 2010.

Carroll W.E., Galileo and the Interpretation of the Bible, „Science \& Education” vol. 8, no 3, 1999.

Coyne G.V., Galileo: for Copernicanism and for the Church, „Zagadnienia Filozoficzne w Nauce” XXXII, 2003.

Coyne G.V., The Church's Most Recent Attempts to Dispel the Galileo Myth, w: E. McMullin (red.), The Church and Galileo, Notre Dame, Indiana: University of Notre Dame Press 2005.

Crombie A.C.C., Nauka średniowieczna i poczq̨tki nauki nowożytnej, t. 2, tłum. S. Łypacewicz, Instytut Wydawniczy Pax, Warszawa 1960.

Dokumentacja procesu Galileusza, tłum. M. Olszańska, K. Sławińska, A. Szostkiewicz, w: J. Życiński (red.), Sprawa Galileusza, Wydawnictwo Znak, Kraków 1991.

${ }^{91}$ Czy znajomość Listu do Wielkiej Księżnej przez Inkwizycję miałaby wpływ na wydarzenia z 1616 i 1633 r.? Czy mogłaby wstrzymać potępienie De revolutionibus? Odpowiedź jest prawie pewna, że nie. Treść Listu prawdopodobnie nie była znana konsultorom („kwalifikatorom”), którzy brali udział w obradach Zgromadzenia Indeksu w 1616 r. A kiedy ogłoszono dekret Zgromadzenia, omówiono kwestie egzegetyczne w Liście zostały skutecznie odsunięte na bok, ledwie je zauważono podczas negocjacji między Galileuszem i jego oskarżycielami w 1633 r.

Por. E. McMullin, Galileo on science and Scripture, s. 319.

92 Jan Paweł II, Przemówienie do Papieskiej Akademii Nauk - 31 października 1992 r. Sprawa Galileusza..., s. 525. 
Fantoli A., Galileo and the Church, w: W. Applebaum (red.), Encyclopedia of the Scientific Revolution from Copernicus to Newton, Taylor \& Francis Group, New York - London 2000.

Fantoli A., Galileusz po stronie Kopernika i po stronie Kościoła, tłum. T. Sierotowicz, Biblos, Tarnów 2001.

Galileo Galilei, A Giovanni Keplero. Padova, 4 agosto 1597, w: idem, Opere, t. 1, Tipografia Torines S. p. A., Torino 1964.

Galileo Galilei, Fragmenty kopernikańskie, tłum. T. Sierotowicz, Wydawnictwa Uniwersytetu Warszawskiego, Warszawa 2005.

Galileo Galilei, Listy kopernikańskie, tłum. T. Sierotowicz i A. Adamski, Biblos, Tarnów 2006.

Hartliński A. (red.), Breviarum Fidei. Wybór doktrynalnych wypowiedzi Kościoła, Księgarnia św. Wojciecha, Poznań 1988.

Hehl W., Galileo Galilei kontrovers. Ein Wissenschaftler zwischen Renaissance-Genie und Despot, Springer Vieweg, Wiesbaden 2017.

Jan Paweł II, Przemówienie do Papieskiej Akademii Nauk-31 października 1992 r. Sprawa Galileusza lekcjq dla współczesnych, w: idem, Dzieła zebrane, t. XIV: Homilie i przemówienia okolicznościowe, Wydawnictwo M, Kraków 2009.

Machamer P. (red.), The Cambridge Companion to Galilei, Cambridge University Press, Cambridge 2006.

McMullin E., Galileo on science and Scripture, w: P. Machamer (red.), The Cambridge Companion to Galilei, Cambridge University Press, Cambridge 2006.

McMullin E., Galileo's Theological Venture, „Zygon” vol. 48, no. 1, March 2013.

McMullin E. (red.), The Church and Galileo, University of Notre Dame Press, Notre Dame, Indiana 2005.

Oestmann G., Rutkin H.D., Stuckrad K. von (red.), Horoscopes and Public Spheres. Essays on the History of Astrology, Walter de Gruyter, Berlin - New York 2005.

Osterhage W.W., Galileo Galilei. At the Threshold of the Scientific Age, Springer, Wachtberg 2018.

Piché D., Parisian Condemnation of 1277, w: H. Lagerlund (red.), Encyclopedia of Medieval Philosophy. Philosophy Between 500 and 1500, Springer, Dordrecht - Heidelberg - London - New York 2011.

Pine M., Double Truth, w: Ph.P. Wiener (red.), Dictionary of the History of Ideas, vol. II, Charles Scribner's Sons, New York 1973.

Rutkin D., Astrology, w: K. Park, L. Daston (red.), Cambridge history of science, t. 3, Cambridge University Press, Cambridge 2008.

Santillana G. de, The Crime of Galileo, The University of Chicago Press, Chicago, Illinois 1995.

Wippel J.F., The Parisian Condemnations of 1270 and 1277, w: J.J. E. Gracia, T.N. Noone (red.), A Companion to Philosophy in the Middle Ages, Blackwell Publishing, Malden - Oxford - Melbourne - Berlin 2002.

Woleński J., Powrót do teorii dwóch prawd, „Filozofia i Nauka” 1(14)/2006.

Życiński J., Proces Galileusza - konflikt prawdy i prawa, w: J. Życiński (red.), Sprawa Galileusza, Wydawnictwo Znak, Kraków 1991. 